\title{
Isolation and characterisation of local strains of Chlamydophila abortus (Chlamydia psittaci serotype 1) from Tunisia
}

\author{
Abdessalem ReKiki ${ }^{\mathrm{a}, \mathrm{b}}$, Karim Sidi-Boumedine ${ }^{\mathrm{b}}$, Armel Souriau ${ }^{\mathrm{b}}$, \\ Jemaa JemLia ${ }^{a}$, Salah Hammami ${ }^{\mathrm{a}}$, Annie Rodolakis ${ }^{\mathrm{b} *}$ \\ a Institut de la Recherche Vétérinaire de Tunisie, La Rabta, Tunis 1006, Tunisia \\ ${ }^{b}$ INRA, Pathologie Infectieuse et Immunologie, 37380 Nouzilly, France
}

(Received 16 July 2001; accepted 9 November 2001)

\begin{abstract}
Chlamydiosis is one of the major diseases that can lead to abortion in ewes. Since 1997, in 5 regions of Tunisia, Chlamydia-related abortions have been reported in 15 sheep and goat flocks. One hundred and sixty-six sera and 50 vaginal swab samples were collected from adult ewes. Chlamydial antigens were detected in $29(58 \%)$ of the vaginal swabs using Enzyme Linked Immunsorbent Assay (ELISA) while $9(18 \%)$ were positive by cell culture. Five strains were recovered from 4 different sheep flocks. Monoclonal antibody profiles and restriction fragment length polymorphism (RFLP) analysis of the 16S-23S rRNA spacer region showed that these isolates were C. abortus. Using amplified fragment length polymorphism (AFLP), these Tunisian strains were shown to exhibit the same pattern as strains isolated in France.
\end{abstract}

Chlamydiosis / diagnosis / Tunisia / isolation / characterisation

Résumé - Isolement et typage de souches locales de Chlamydophila abortus (Chlamydia psittaci sérotype 1). La chlamydiose est une des principales cause d'avortements infectieux en Tunisie. Lors de la période d'agnelage de 1997, 166 prises de sang et 50 écouvillons vaginaux ont été prélevés dans 15 troupeaux répartis sur 5 gouvernorats et ayant eu des problèmes d'avortements. Des chlamydia ont été mises en évidence dans 29 (58 \%) écouvillons vaginaux appartenant à 13 troupeaux différents par ELISA directement sur l'écouvillon vaginal et $9(18 \%)$ après multiplication sur cellules. Cinq souches tunisiennes appartenant à 4 troupeaux différents ont ainsi pu être isolées. Leur caractérisation par une panoplie d'anticorps monoclonaux et par étude du profil de restriction de l'espace intergénique 16S-23S a démontré qu'elles appartenaient toutes à l'espèce Chlamydophila abortus. Par

*Correspondence and reprints

Tel.: (33) 2474277 00; fax: (33) 2474277 79; e-mail: Annie.Rodolakis@tours.inra.fr 
amplification sélective de fragment de restriction les souches tunisiennes présentaient le profil caractéristique des souches françaises.

Chlamydiosis / diagnostic / Tunisie / isolement / caractérisation

\section{INTRODUCTION}

The Chlamydiaceae are ubiquitous throughout the world and infect both humans and animals. These obligate intracellular bacteria exhibit a unique life cycle with two morphologically different infectious and reproductive forms: the elementary body (EB) and reticular body (RB) forms [12, 14]. Recently, phylogenetic analysis based on 16S-23S ribosomal RNA sequences has led to the classification of the Chlamydiaceae family into two genera: Chlamydia and Chlamydophila [8]. Chlamydophila abortus corresponds to the strains that previously belonged to serotype 1 of Chlamydia psittaci, the causative agent of enzootic abortion of ewes (EAE). Clinically, EAE is characterized by abortion in the last 5 weeks of pregnancy or the production of weak and generally premature lambs. Abortions due to chlamydial infection have major economic implications in ruminant breeding. In flocks encountering EAE for the first time, abortion may occur in up to $30 \%$ of pregnant sheep, and $70 \%$ of pregnant goats [18]. In flocks in which EAE is endemic however, abortion rates are lower with annual losses of 5-10\%. Fertility rates are also decreased by infection with Chlamydophila abortus [18]. Other manifestations of infection include pneumonitis, arthritis, pericarditis, enteritis, and conjunctivitis [15].

In northern and central Tunisia, small ruminant farming is an essential resource for rural populations. Serological surveys conducted on the sheep flocks in these areas have revealed that of the main investigated causes of abortion (Chlamydiosis, Q-Fever,
Brucellosis, Salmonellosis, and Border disease) chlamydial infection was detected in $60 \%$ [6]. However no data related to attempts to isolate and characterise C. abortus have been published yet in Tunisia. Therefore, the aim of this work was to isolate and characterise local strains of Chlamydophila in order to compare with strains of different geographical origin.

\section{MATERIALS AND METHODS}

\subsection{Samples}

In 1997, sheep and goat flocks with a demonstrated problem of abortion were selected for this study. Blood and vaginal swabs were collected from females that had just recently aborted. A total of 166 sera and 50 vaginal swabs were obtained from 15 herds located in 5 different regions of Tunisia (Tab. I). Flocks 13 and 14 (Tab. I) were visited twice and three times respectively after new abortion episodes. The number of sampled animals was not related to the size of the flock. The stage of gestation at which the sampled animals had aborted was recorded. Vaginal swabs were placed directly into transport medium for chlamydiae containing Sucrose-PhosphateGlutamine buffer (SPG) [22]. They were kept at $4{ }^{\circ} \mathrm{C}$ during transportation, then stored at $-70{ }^{\circ} \mathrm{C}$ until use.

\subsection{Isolation of chlamydia and DNA extraction}

Bacterial isolation attempts were performed using both plaque assays and blind 
Table I. Serology and Chlamydial antigen detection in ovine and caprine flocks.

\begin{tabular}{|c|c|c|c|c|c|c|c|}
\hline \multicolumn{2}{|r|}{ Flocks } & \multicolumn{2}{|c|}{ Serology $(C F T)^{\mathrm{a}}$} & \multicolumn{4}{|c|}{ Detection of antigen by ELISA } \\
\hline No. & No. animals & No. sera tested & titers & $\mathrm{Ab}^{\mathrm{b}}$ & $\operatorname{Lam}^{\mathrm{b}}$ & $\mathrm{VS}^{\mathrm{c}}$ & $\mathrm{CC}^{\mathrm{c}}$ \\
\hline \multicolumn{8}{|l|}{ Ovine } \\
\hline 1 & 54 & 10 & $>1 / 10$ & 1 & 0 & 1 & 0 \\
\hline 2 & 300 & 2 & $>1 / 10$ & 0 & 2 & 2 & 1 \\
\hline 3 & 150 & 3 & $>1 / 10$ & 0 & 1 & 1 & 0 \\
\hline 4 & 200 & 1 & $>1 / 10$ & 0 & 1 & 1 & 1 \\
\hline 5 & 178 & 10 & $>1 / 10$ & 0 & 1 & 1 & ND \\
\hline 6 & 248 & 10 & $>1 / 10$ & 4 & 0 & 3 & 0 \\
\hline 7 & 305 & 10 & $1 / 40(1)$ & 1 & 0 & 0 & ND \\
\hline 8 & 202 & 10 & $1 / 40(1)$ & 1 & 0 & 1 & ND \\
\hline 9 & 351 & 13 & $1 / 40(2)$ & 6 & 2 & 3 & 1 \\
\hline 10 & 293 & 5 & $1 / 40(2)$ & 1 & 0 & 0 & 0 \\
\hline 11 & 250 & 10 & 1/640 (3) & 2 & 0 & 2 & 1 \\
\hline 12 & 239 & 12 & 1/320(8) & 8 & 0 & 6 & 3 \\
\hline 13 & 250 & 28 & $1 / 320(7)$ & 5 & 3 & 4 & 2 \\
\hline 14 & 225 & 32 & 1/160 (1) & 7 & 0 & 1 & 0 \\
\hline \multicolumn{8}{|c|}{ Caprine } \\
\hline \multirow[t]{2}{*}{15} & 14 & 10 & $1 / 320(1)$ & 4 & 0 & 3 & 0 \\
\hline & & 166 & & 40 & 10 & 29 & 9 \\
\hline
\end{tabular}

${ }^{a}$ CFT: Complement Fixation Test (only Highest titers are indicated with corresponding number of samples). ${ }^{b}$ Number of vaginal swabs collected among aborted (Ab) or lambed (Lam) animals. ${ }^{c}$ Number of samples positive for chlamydial antigen ELISA, directly on vaginal swabs (VS) and after cell culture (CC).

passages on monolayer cell cultures [17]. Vaginal swabs were centrifuged at $4500 \mathrm{~g}$ for $15 \mathrm{~min}$ at $4{ }^{\circ} \mathrm{C}$. For plaque assays, McCoy cell monolayers in P6 (Falcon, Becton Dickinson Lab ware, Franklin lakes, USA) were inoculated with $200 \mu \mathrm{L}$ of the supernatant. For blind passages, $500 \mu \mathrm{L}$ were added to McCoy cell monolayers in $25 \mathrm{~cm}^{2}$ flasks (Falcon, Becton Dickinson Lab ware, Franklin lakes, USA). After incubation at $37{ }^{\circ} \mathrm{C}$ for $2 \mathrm{~h}$ in a $5 \% \mathrm{CO}_{2}$ atmosphere, inocula were removed and replaced with medium. Two blind passages were performed for all cell cultures. Positive cultures and plaque cloned chlamydiae were grown in specific pathogen-free eggs and harvested yolk sacs were frozen at $-80{ }^{\circ} \mathrm{C}$. The bacteria were purified according to Caldwell et al. [5] and stored at $-20{ }^{\circ} \mathrm{C}$. Genomic DNA was prepared from purified chlamydiae as described by Boumedine and Rodolakis [3].

\subsection{ELISA}

Chlamydial antigens were detected in vaginal swab samples or in cell cultures by ELISA, using a commercial diagnostic kit available for $C$. trachomatis detection (DAKO diagnostics, IDEIA ${ }^{\mathrm{TM}}$, United Kingdom). The IDEIA Chlamydia Test was used as instructed by the manufacturers.

\subsection{Microimmunofluorescence (MIF)}

An MIF assay was performed as described by Salinas et al. [19] and Chlamydial antigens were detected using different monoclonal antibodies (Mab): RC6C4 
(specific for Chlamydiaceae), CA5G11 (specific for C. abortus), [19] and 3DA1A7 (specific for C. pecorum) [20].

\subsection{Restriction Fragment Length Polymorphism (RFLP) of the 16S-23S rRNA spacer region}

RFLP analysis was performed according to Meijer et al. [13]. Briefly, amplified DNA fragments of the intergenic spacer 16S-23S rRNA were digested using $B g l$ II and Pst I. The resulting fragments were separated by $1.5 \%$ agarose gel electrophoresis and stained with an ethidium bromide solution.

\subsection{Amplified Fragment Length Polymorphism (AFLP)}

This technique was performed as outlined by Boumedine and Rodolakis [3]. Briefly, 1-2 $\mu \mathrm{g}$ of purified genomic DNA were added to restriction endonuclease, adapters and T4 DNA ligase (Promega corporation, USA) for $3 \mathrm{~h}$ at $37^{\circ} \mathrm{C}$. PCR amplification was then performed on $20 \mathrm{ng}$ of the adapted DNA using oligonucleotides complementary to the adapters as primers. Primers with 3 nucleotides extending beyond the adapters at the 3 ' end were selected (P-GGT). The amplified products were separated by standard horizontal gel electrophoresis on a $1.5 \%$ agarose gel in electrophoresis buffer and stained with an ethidium bromide solution. In addition to the 5 isolates, $\mathrm{AB} 7$ was used as reference strain for C. abortus [10], as well as iB1 strain for C. pecorum [16].

\subsection{Serology}

Demonstration of anti-Chlamydophila antibodies in serum samples employed the Complement Fixation Test (CFT) which uses an antigen (Vetoquinol-Lure-France) that is common to all the members of the
Chlamydiacae family. Titters equal to $1 / 40$ were considered doubtful, and those equal or greater than $1 / 80$ were considered positive [15].

\section{RESULTS}

\subsection{Chlamydial antigen detection}

Chlamydiae were detected by ELISA in $29 / 50(58 \%)$ vaginal swabs from 13 different flocks, 5 of which were positive with the CFT (Tab. I). These vaginal swabs were collected between 0 and 15 days after abortion and on the day following lambing for 6 others. Nine samples $/ 50$ from 6 different flocks were positive after culture. Of these, only 5 strains from 4 different ovine flocks were isolated (Tab. II). One strain came from an ewe that had lambed at-term viable lambs. One of these lambs developed conjunctivitis but the chlamydial origin of this conjunctivitis was not investigated.

\subsection{Characterization}

The MIF tests showed that all isolates reacted against Mabs RC6C4 and CA5G11 in the same manner as did the reference strain C. abortus AB7. No reaction was observed with Mab 3DA1A7 specific to C. pecorum (Tab. III). PCR-RFLP analysis with $M s p$ I

Table II. Chlamydophila strains isolated in Tunisia.

\begin{tabular}{lcc}
\hline Strain & Samples & Location of origin \\
\hline ABt 5 & Abortion & Enfhida 14 \\
ABt15 & Lambing & Enfhida 26 \\
ABt35 & Abortion & Enfhida 26 \\
MBt34 & Lambing & Akkara \\
ABt sw & Abortion & Swayah \\
\hline
\end{tabular}


Table III. Reactivity of monoclonal antibodies (Mab) with selected reference and Tunisians strains of $C$. abortus using a microimmunofluorescence test.

\begin{tabular}{|c|c|c|c|c|c|c|c|}
\hline \multirow[b]{2}{*}{$M a b$} & \multicolumn{2}{|c|}{ Reference strains } & \multicolumn{5}{|c|}{ Tunisian isolates } \\
\hline & $A B 7$ & $i B 1$ & ABt 5 & ABt 15 & ABt35 & MBt34 & ABtsw \\
\hline RC6C4 & +++ & +++ & +++ & +++ & +++ & +++ & +++ \\
\hline CA5G11 & +++ & --- & +++ & +++ & +++ & +++ & +++ \\
\hline 3DA1A7 & --- & +++ & --- & --- & --- & --- & --- \\
\hline
\end{tabular}

+++ : Bright fluorescence observed at dilution 1:1000.

---: No visible reaction at dilution 1:1000.

or Pst I of 16S-23S RNA showed that the restriction profiles of all isolates were the same as the reference strain C. abortus AB7 (Fig. 1). AFLP with the selective primer P-GGT allowed the amplification of two fragments (1 $000 \mathrm{bp}$ and $500 \mathrm{bp}$ ) from the five Tunisian strains tested and the amplification pattern was similar to the $C$. abortus reference strain AB7 (Fig. 2).

\section{DISCUSSION}

This study was the first attempt to isolate and characterize chlamydial strains responsible for ovine abortion in different areas in Tunisia.

Chlamydial antigens were detected by ELISA in $58 \%$ of the sampled vaginal swabs. All the positive samples had been collected between 0 and 15 days after abortion or on the day following lambing. Chlamydial shedding has been shown to decrease rapidly and become intermittent following abortion [21]. Therefore the vaginal swab results depend on the sampling dates, and negative results might reflect a too late sampling. However, timely collection of samples soon after abortion or lambing is difficult to perform in Tunisia, especially since our laboratory is located far from farmers.

One of the nine ELISAs performed on positive cell cultures was initially negative.
This finding of chlamydial isolation techniques proving more sensitive than direct detection by ELISA is in accordance with those in human medicine [2]. However, of vaginal swabs positive by ELISA, only 9 grew out chlamydiae and only 5 strains were isolated. This could be explained mainly by the death of the organisms during transport to the laboratory as chlamydiae are very fragile when extracellular [22, 23]. In addition, the sampling conditions in the field were not optimal. In human medicine, patient sampling collection occurs rapidly, under ideal conditions, and in close proximity to the diagnostic laboratory. C. abortus was isolated from two ewes, which had lambed at-term viable lambs. This emphasises the fact that $C$. abortus can induce latent infections. These apparently healthy but infected sheep may shed chlamydiae, and are therefore a potential source of contamination for other flocks and pregnant women [4].

Only 5 of the 13 flocks from which ELISA positive vaginal swabs were sampled, were positive to CFT. This is probably due to the time of sampling, as we have previously shown that antibodies sometimes decreased at the time of abortion or lambing and reached their higher level 4 to 6 weeks latter [11]. For this purpose it is recommended to performed serological diagnosis of abortion 3 to 6 weeks after abortion and lambing [15] as in Q fever also it is possible 
(A)

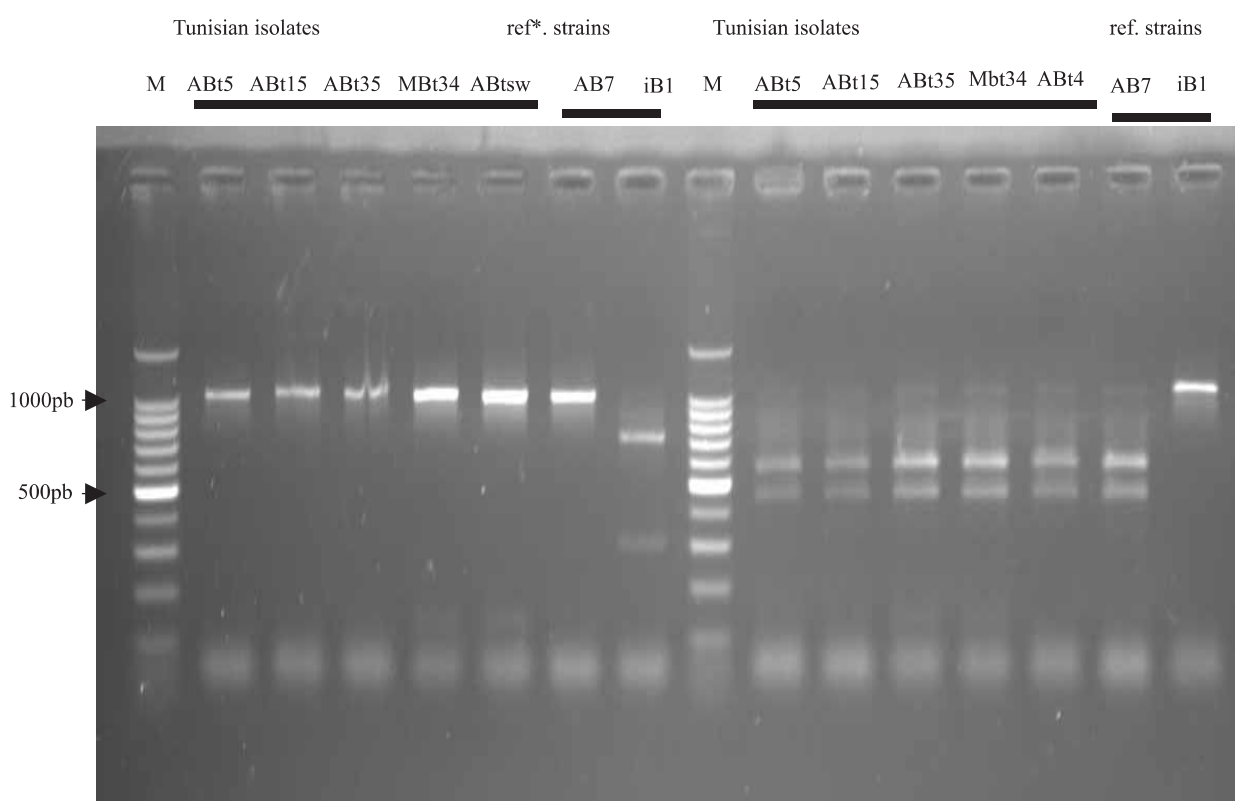

Figure 1. RFLP profiles of the 16S-23S rRNA region spacer of chlamydophila isolates after digestion with $B g l$ II (A) and Pst I (B) and electrophoresis on 1.5\%. *Reference.

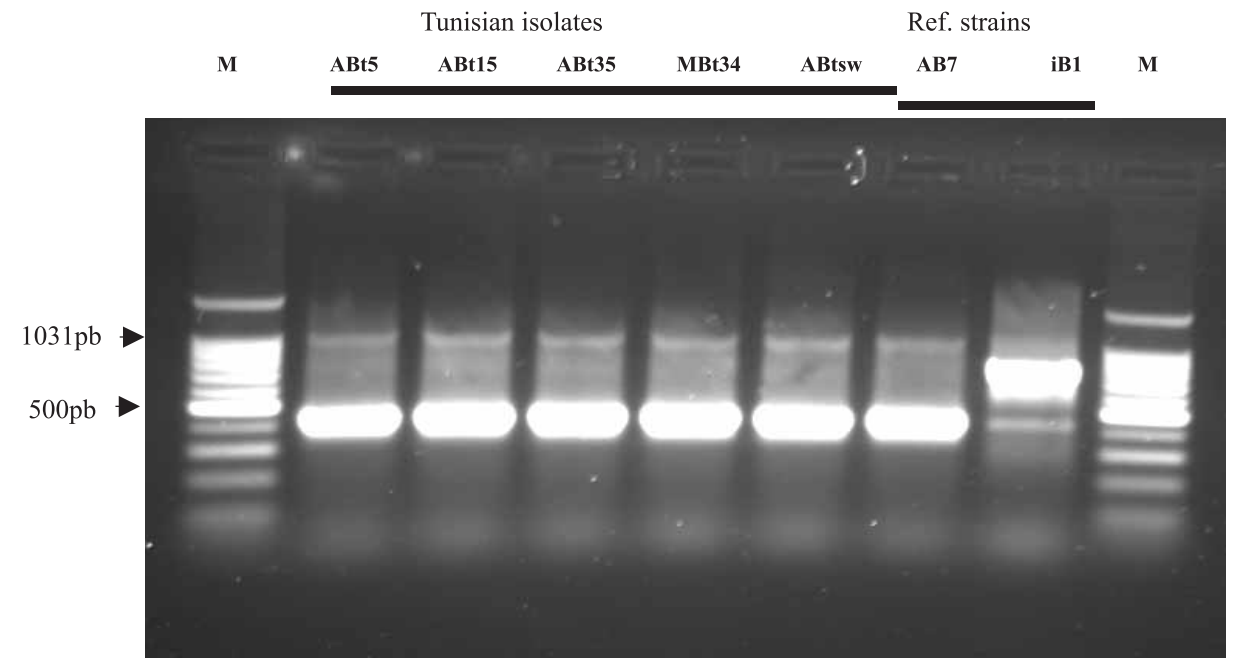

Figure 2. AFLP pattern obtained with the primer P-GGT. All Tunisians strains exhibited the same profile as the reference strain $\mathrm{AB} 7$. 
to find serologically negative ewes shedding Coxiella [1].

No discrimination between the new isolates and the reference strain $\mathrm{AB} 7$ isolated in France from an ovine abortion [10], was demonstrated using either PCR-RFLP of the 16S-23S RNA intergenic spacer or MIF. These methods have been used to characterise chlamydial strains $[7,9,13]$ and to type $C$. trachomatis with relative ease. These techniques, however, were enable to differentiate among $C$. abortus strains [8, $19]$. For this purpose, only AFLP analysis has been used so far [3]. AFLP analysis has revealed that these strains were closely related to C. abortus strains isolated in France but different from those isolated in the United Kingdom, Greece and the USA [3]. This suggests that abortive chlamydiosis in Tunisia shares the same ancestor as French strains. The use of different enzyme and primer pairs in the application of both methods described by Boumedine and Rodolakis [3] or by Vos et al. [24] will be used in further study to answer the question of a common origin between French and Tunisian strains.

Our preliminary investigation showed the importance of $C$. abortus as the cause of abortion in sheep flocks. This study was the first to isolate and perform initial characterisation of the Tunisian strains of $C$. abortus. This work will be made more complete by including isolations from ovine and other species (for example. caprine), and from flocks localized in different regions of Tunisia. Molecular and comparative studies between local and other strains will be continued.

\section{ACKNOWLEDGEMENTS}

The authors are grateful to Skaneta Tabou for his help with reviewing the manuscript (MD, Renal Fellow, Renal Unit, Massachusetts General hospital and Harvard Medical School). We also thank
Dr Lassoued Habib for his help collecting samples and to the "Secrétariat d'État Tunisien à la recherche scientifique et à la technologie" and the "Institut Français de Coopération".

\section{REFERENCES}

[1] Berri M., Souriau A., Crosby M., Crochet D., Lechopier P., Rodolakis A., Relationships between the shedding of Coxiella burnetii, clinical signs and serological responses of 34 sheep, Vet. Rec. 148 (2001) 502-505.

[2] Black C.M., Current methods of laboratory diagnosis of Chlamydia trachomatis infections, Clin. Microbiol. Rev. 10 (1997) 160-184.

[3] Boumedine K.S., Rodolakis A., AFLP allows the identification of genomic markers of ruminant Chlamydia psittaci strains useful for typing and epidemiological studies, Res. Microbiol. 149 (1998) 735-744.

[4] Buxton D., Barlow R.M., Finlayson J., Anderson I.E., Mackellar A., Observations on the pathogenesis of Chlamydia psittaci infection of pregnant sheep, J. Comp. Pathol. 102 (1990) 221237.

[5] Caldwell H.D., Kromhout J., Schachter J., Purification and partial characterization of the major outer membrane protein of Chlamydia trachomatis, Infect. Immun. 31 (1981) 1161-1176.

[6] Dlissi E., Hammami S., Seghaïer Ch., Russo P., Sanchis R., Rekiki A., Proceeding XV Congrès Maghrébin: Incidence comparative des maladies abortives des petits ruminants en Tunisie, ANMVT (Ed.), Tunisie, 1998, pp. 70-71.

[7] Eb F., Orfila J., Serotyping of Chlamydia psittaci by the micro-immunofluorescence test: isolates of ovine origin, Infect. Immun. 37 (1982) 1289-1291.

[8] Everett K.D., Bush R.M., Andersen A.A., Emended description of the order Chlamydiales, proposal of Parachlamydiaceae fam. nov. and Simkaniaceae fam. nov., each containing one monotypic genus, revised taxonomy of the family Chlamydiaceae, including a new genus and five new species, and standards for the identification of organisms, Int. J. Syst. Bacteriol. 49 (1999) 415-440.

[9] Everett K.D., Chlamydia and Chlamydiales: more than meets the eye, Vet. Microbiol. 75 (2000) 109-126.

[10] Faye P., Charton L., Mage C., Layec C., Propriétés hémagglutinantes du 'virus' de l'avortement enzootique des petits ruminants (souches de Rakeia d'origine ovine et caprine), Bull. Acad. Vét. 45 (1972) 169-173. 
[11] Fuensalida-Drapper E., Rodolakis A., Kinetics of the complement fixing and immunofluorescent antibody response in experimental chlamy- diosis in ewes, Ann. Rech. Vet. 9 (1978) 505-516.

[12] Litwin J., The growth cycle of the psittacosis group of organisms, J. Infec. Dis. 109 (1959) 129-160.

[13] Meijer A., Kwakkel G.J., de Vries A., Schouls L.M., Ossewaarde J.M., Species identification of Chlamydia psittaci isolates by analysing restriction fragment length polymorphism of the 16S-23S rRNA Spacer region, J. Clin. Microbiol. 35 (1997) 1179-1183.

[14] Moulder J.W., Interaction of chlamydiae and host cells in vitro, Microbiol. Rev. 55 (1991) 143-190.

[15] Rodolakis A., Salinas J., Papp J., Recent advances on ovine chlamydial abortion, Vet. Res. 29 (1998) 275-288.

[16] Rodolakis A., Souriau A., Variation in the virulence of strains of Chlamydia psittaci for pregnant ewes, Vet. Rec. 125 (1989) 87-90.

[17] Rodolakis A., Chancerelle L., Plaque assay for Chlamydia psittaci in tissue samples, Ann. Microbiol. 128 (1977) 81-85.

[18] Rodolakis A., Les infections à Chlamydia psittaci: acquisitions récentes et applications au diagnostic et à l'épidémiologie des chlamydioses aviaires, canines et félines, Prac. Méd. Chir. Anim. Comp. 28 (1993) 321-330.
[19] Salinas J., Souriau A., Cuello F., Rodolakis A., Antigenic diversity of ruminant Chlamydia psittaci strains demonstrated by the indirect microimmunofluorescence test with monoclonal antibodies, Vet. Microbiol. 43 (1995) 219-226.

[20] Salinas J., Souriau A., De Sa C., Andersen A.A., Rodolakis A., Serotype 2-specific antigens from ruminant strains of Chlamydia pecorum detected by monoclonal antibodies, Comp. Immunol. Microbiol. Infect. Dis. 19 (1996) $155-161$.

[21] Souriau A., Rodolakis A., Rapid detection of Chlamydia psittaci in vaginal swabs of aborted ewes and goats by enzyme linked immunosorbent assay (ELISA), Vet. Microbiol. 11 (1986) 251-259.

[22] Spencer W.N., Johnson W.A., Simple transport medium for isolation of Chlamydia psittaci from clinical material, Vet. Rec. 3 (1983) 535-536.

[23] Stary A., Correct samples for diagnostic tests in sexually transmitted diseases: which sample for which test? FEMS Immunol. Med. Microbiol. 15 (1999) 455-459.

[24] Vos P., Hogers R., Bleeker M., Reijans M., van de Lee T., Hornes M., Frijters A., Pot J., Peleman J., Kuiper M., AFLP, a new technique for DNA fingerprinting, Nucleic. Acids Res. 23 (1995) 4407-4414.

To access this journal online: www.edpsciences.org 